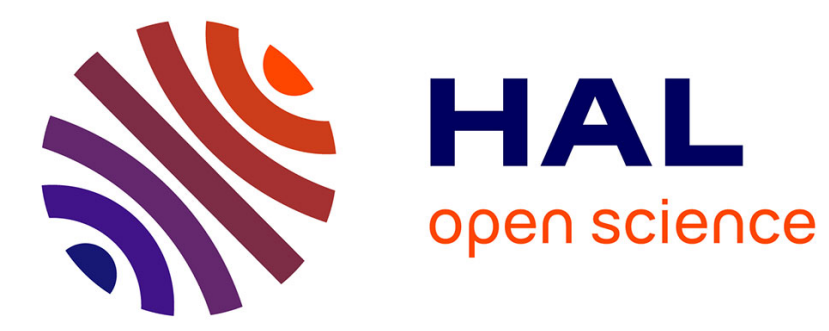

\title{
A Strategic Approach for Automation Technology Initiatives Selection
}

\author{
Maria Kollberg Thomassen, Børge Sjøbakk, Erlend Alfnes
}

\section{To cite this version:}

Maria Kollberg Thomassen, Børge Sjøbakk, Erlend Alfnes. A Strategic Approach for Automation Technology Initiatives Selection. IFIP International Conference on Advances in Production Management Systems (APMS), Sep 2014, Ajaccio, France. pp.288-295, 10.1007/978-3-662-44733-8_36 . hal-01387259

\section{HAL Id: hal-01387259 \\ https://hal.inria.fr/hal-01387259}

Submitted on 25 Oct 2016

HAL is a multi-disciplinary open access archive for the deposit and dissemination of scientific research documents, whether they are published or not. The documents may come from teaching and research institutions in France or abroad, or from public or private research centers.
L'archive ouverte pluridisciplinaire HAL, est destinée au dépôt et à la diffusion de documents scientifiques de niveau recherche, publiés ou non, émanant des établissements d'enseignement et de recherche français ou étrangers, des laboratoires publics ou privés. 


\title{
A Strategic Approach for Automation Technology Initiatives Selection
}

\author{
Maria Kollberg Thomassen ${ }^{1}$, Børge Sjøbakk ${ }^{1}$, Erlend Alfnes ${ }^{2}$ \\ ${ }^{1}$ SINTEF Technology and Society, Industrial Management, \\ P.O. Box 4760 Sluppen, N-7465 Trondheim, Norway \\ \{maria.thomassen, borge.sjobakk\}@sintef.no \\ ${ }^{2}$ Department of Production and Quality Engineering, \\ Norwegian University of Science and Technology, NTNU \\ erlend.alfnes@ntnu.no
}

\begin{abstract}
Despite the rapid development of new manufacturing technologies, a large portion of adoptions fail to achieve expected benefits. Existing models for technology selection are criticized for requiring large computations, and for being time consuming and difficult to use. This paper presents a strategic approach to support decision-makers in automation technology selection that is efficient and easy to apply in practice. It involves technology strategy decisions, process and technology analyses, technology/process ranking and considerations on investment and implementation. The approach has been developed through literature reviews and close collaboration with two case companies, utilizing the action research method. Its use is illustrated in an ongoing automation project at a world leading supplier of plastic pipes systems.
\end{abstract}

Keywords: Operations strategy, automation, process technology, strategic approach, technology selection, high variety production

\section{$1 \quad$ Introduction}

Despite rapid developments of new manufacturing technologies, a large percentage of technology adoptions fail to achieve expected benefits $[1,2]$. The risk of unsuccessful investments in advanced production equipment is high. Often, companies have insufficient foundation for investments decision-making [2]. Consequently, many companies tend to make large investments in equipment that give only limited payoff [3], often resulting in too much capacity, excess functionality and equipment that does not fulfill its potential [4]. A rapid increase in the number of available technologies and technology complexity has implied more challenging decision-making $[5,6]$. Literature proposes numerous approaches to technology selection [7-9]. However, existing models are criticized for requiring large computations and for being time consuming and difficult to use due to their high level of sophistication $[10,11]$.

The purpose of this research is to develop an approach to support decision-makers in automation technology selection. The approach is self-explanatory, simple to apply

adfa, p. 1, 2011.

(C) Springer-Verlag Berlin Heidelberg 2011 
and permits rapid prioritization of automation initiatives. The study expects to contribute to improved practices of how companies can arrive at better quality automation decisions by adopting a systematic approach.

The approach was developed using action research, including literature investigations and discussions with representatives of two case companies; a supplier of hightech ship equipment and a plastic pipe system supplier. The companies provided detailed insights into their experiences from historical and ongoing automation processes, as well as their needs of how current practices should be improved.

The rest of the paper is structured as follows. A theoretical background is given, followed by a presentation of the suggested approach. An illustrative example of how the approach can be used is also included. After this, conclusions are presented.

\section{Theoretical background}

Most of the traditional literature on automation, with focus on high-volume, lowvariety production, claims that automation is highly suitable for standardized processes and products in high volumes [12]. Processes characterized by specific product features or high level of customization have traditionally been challenging to automate [14]. However, more flexible technologies have emerged in recent years that permit more efficient automation also of non-standard processes [15]. Decreased technology prices in combination with increased labor costs enable automation in areas that have not earlier been viable [13]. Consequently, the interest for automation is growing also among companies characterized by high variation and typically manual based labor. With this development, automation decisions become even more challenging.

A relatively large body of literature addresses technology selection and justification issues in manufacturing companies. There is especially a wide range of approaches for technology selection [7] and justification of new technology investments [8]. Basically, technology selection methodologies focus on how to select the best technology for a specific process whereas investment appraisal techniques provide support for analysing investment justification problems of specific equipment.

There is a large variation in process focus among existing approaches, meaning that they are developed for different purposes and settings. For example, Torkkeli and Tuominen [6] propose a process for integrating technology selection to a part of core competence management in large manufacturing companies, whereas the technology selection framework of Farooq and O'Brien [16] aims to ensure alignment of technology decisions to supply chain objectives. Moreover, most approaches are based upon specific methods that imply detailed and time-consuming analyses and calculations for a defined technology or process [e.g. 17, 18, 19]. Only a few approaches have been identified that address applicability or usability aspects and provide guidance on usage of approaches [20,21]. Social and environmental aspects are rarely considered in current approaches.

A synthesis of the main phases of different technology decision-making approaches and typical areas of analysis in a selection of literature is presented in Table 1. 
Table 1. Main phases and typical areas of analysis identified in literature

\begin{tabular}{lll}
\hline Main phase & Typical areas of analysis & Refs. \\
\hline \multirow{2}{*}{ Strategic } & Market characteristics, evolution and trends & {$[1,6,9$,} \\
& Manufacturing vision and strategy & 16,18, \\
& Core competencies definition & $22]$ \\
& Business objectives, opportunities and competitive priorities & \\
& Strategic planning incl. technology strategy, mission and purpose & \\
\hline \multirow{2}{*}{ Operations } & Resources and competences & {$[9,18$,} \\
& Operational goals and requirements & $22,23]$ \\
& Product characteristics & \\
\hline \multirow{2}{*}{ Technology } & Technology alternatives identification & {$[6,9,16$,} \\
& Technology characteristics and performance & 18,19, \\
& Technology impact assessment incl. risk & $22-24]$ \\
\hline Investment & Technical, manufacturing and financial criteria definition & {$[9,17$,} \\
& Economic/financial, strategic and analytical justification & $18]$ \\
\hline \multirow{2}{*}{ Implemen- } & Deployment and protection of core competencies & {$[6,9,18]$} \\
& Training and installation & \\
& Technical knowledge & \\
\hline
\end{tabular}

\section{The Suggested Technology Selection Approach}

The suggested technology selection approach is described in this section. It has been developed based on the literature and input from the two case companies. The companies seek increased efficiency in order to retain their production in Norway. Their high labor costs make automation the most efficient means of competitiveness. The companies are already highly automated; however, automation is applied in a rather "traditional" manner and includes mainly standard processes and simple products.

The approach aims to support prioritization of automation initiatives so that a few projects can be selected for more detailed analysis and evaluation for acquisition and implementation. Even though the process is structured in five steps, it is assumed that the process is highly iterative in practice and recurrence is a natural part of the process, and that findings in subsequent steps may lead to reassessment of previous ones.

The first step deals with technology strategy decisions. A key question is how manufacturing can support the business strategy in terms of various performance metrics. Corporate responsibility and environmental policies should be used to shape main principles for responsible manufacturing in terms of workplace health, safety practices and environmental stewardship. Industry trends and company technology capabilities are used to decide whether the company should be an 'innovator' or a 'follower' and whether technologies are to be developed in-house or purchased.

In step 2, process analysis, the overall manufacturing system should be understood in terms of: (1) its performance requirements in terms of volumes, batch sizes, capacity and utilization, for instance; (2) main products and their processing requirements, with regard to geometry and material specifications; (3) the processing activities performed by the manufacturing system. Thereafter, process candidates can be identified by calculating current and future processing times in machine hours and man hours 
for each process, selecting labor intensive candidates for automaton and adding candidates based on requirements for performance and responsible manufacturing.

Technology alternatives are analyzed in step 3. For each process candidate, potential technologies should be identified. For each technology, its maturity should be assessed together with the level of adaptation required to perform the process using the technology. Each technology should also be evaluated in terms of what performance it implies for the process. Selected technologies should be suitable for each process and be evaluated based upon short-term and long-term considerations.

Step 4 involves the ranking of process/technology combinations where process/technology candidates are assessed in terms of strategic importance and ease of implementation. Priority should be given to initiatives with a strong strategic impact that are also easy to implement.

Investment and implementation aspects are considered in step 5, where the economic viability is tested for the prioritized candidates, usually through development of business cases. Specific analyses to be carried out typically vary with the information requested by the company's board of directors. For viable projects, implementation plans with defined milestones and responsibilities should be developed. The main elements of the suggested approach are summarized in Table 2.

Table 2. The suggested approach

\begin{tabular}{|c|c|c|c|}
\hline Step & Input & Assessments and Decisions & Output \\
\hline $\begin{array}{l}\text { Technol- } \\
\text { ogy strat- } \\
\text { egy }\end{array}$ & $\begin{array}{l}\text { Business strategy } \\
\text { CSR strategy } \\
\text { Technology trends } \\
\text { Competences }\end{array}$ & $\begin{array}{l}\text { Define manuf. competitive priorities } \\
\text { and responsibility objectives } \\
\text { Define innovation position for main } \\
\text { technologies }\end{array}$ & $\begin{array}{l}\text { Technology } \\
\text { strategy } \\
\text { Areas of } \\
\text { interest for } \\
\text { automation }\end{array}$ \\
\hline $\begin{array}{l}\text { Process } \\
\text { analysis }\end{array}$ & $\begin{array}{l}\text { Manuf. performance } \\
\text { and responsibility re- } \\
\text { quirements } \\
\text { Product processing } \\
\text { requirements } \\
\text { Bill of manuf. processes }\end{array}$ & $\begin{array}{l}\text { Map processes } \\
\text { Select labour intensive processes } \\
\text { Add candidates based on additional } \\
\text { requirements }\end{array}$ & $\begin{array}{l}\text { Manufactur- } \\
\text { ing process } \\
\text { candidates }\end{array}$ \\
\hline $\begin{array}{l}\text { Technol- } \\
\text { ogy anal- } \\
\text { ysis }\end{array}$ & $\begin{array}{l}\text { Literature and patents } \\
\text { Conferences, fairs } \\
\text { Expert knowledge } \\
\text { Internal documents and } \\
\text { workshops }\end{array}$ & $\begin{array}{l}\text { Identify alternative technologies } \\
\text { Assess technology maturity and per- } \\
\text { formance } \\
\text { Select technologies for each candidate } \\
\text { process }\end{array}$ & $\begin{array}{l}\text { Technolo- } \\
\text { gy/process } \\
\text { combina- } \\
\text { tions }\end{array}$ \\
\hline $\begin{array}{l}\text { Technol- } \\
\text { ogy/ } \\
\text { process } \\
\text { ranking }\end{array}$ & $\begin{array}{l}\text { Accumulated input } \\
\text { from step 1-3 }\end{array}$ & $\begin{array}{l}\text { Assess strategic importance } \\
\text { Assess ease of implementation } \\
\text { Select project candidates based on } \\
\text { strategic impact and ease of imple- } \\
\text { mentation }\end{array}$ & $\begin{array}{l}\text { Ranked } \\
\text { technology } \\
\text { projects }\end{array}$ \\
\hline $\begin{array}{l}\text { Inv. and } \\
\text { imple- } \\
\text { mentation }\end{array}$ & $\begin{array}{l}\text { Sales forecasts } \\
\text { Acquisition costs } \\
\text { Operating cost } \\
\text { Supplier quotations }\end{array}$ & $\begin{array}{l}\text { Analyse investments } \\
\text { Assess suppliers } \\
\text { Assess competence requirements } \\
\text { Select projects and plan implementa- } \\
\text { tion }\end{array}$ & $\begin{array}{l}\text { Time } \\
\text { phased } \\
\text { technology } \\
\text { implementa- } \\
\text { tion plan }\end{array}$ \\
\hline
\end{tabular}




\section{$4 \quad$ Application of the Approach}

This chapter describes how the suggested approach for structuring and selection of potential automation initiatives is applied in one of the case companies. The company produces pipes for water, sewage, gas, cable protection and electrical installations. Its standard products come in a large number of variants depending on aspects related to for instance color, material and geometry including shape, circumference and length. Non-standard variants are made in-house in a separate department. Here, standard products from the inventory are customized by means of manual labor and low-level, semi-automated process technology.

Step 1: Technology strategy decisions. In order to compete against low-cost competitors and retain production in Norway, cost efficiency is a key competitive priority for the company. As such, any technology investments should contribute to reduced operating costs. Further, the company continuously works on improving its workplace health and safety practices, and there is high priority on eliminating straining, manual and repetitive tasks. Being a Norwegian subsidiary of one of the world's leading suppliers of plastic pipe systems, the company seeks to be an innovator. Since the company has limited capabilities to develop new technology in-house, they primarily seek to acquire new equipment from external suppliers.

Step 2: Process analysis. The manufacturing performance requirements are mapped next, including an assessment of the production data over the last four years in terms of number of parts produced, cycle time, share of man hours, service level, other delivery terms, and so on. This is used to identify main products (plastic pipes and components in a range of variants) and map their processing requirements. The main processes carried out to produce these products are identified, including plastic extrusion or injection molding for standard product variants, with subsequent forming, joining (e.g. welding) and assembly for customized products. Products are grouped based on similarities in processing and product characteristics. For each of these groups, aggregate processing times in machine-hours and man-hours are calculated, see Fig. 1.

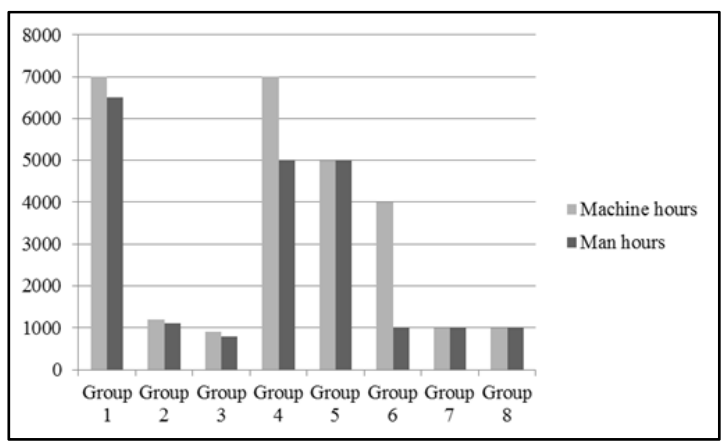

Fig. 1. Example of labor intensity mapping in the case company 
This overview is used to select the most labor intensive candidates. Groups with high man-hours (1, 4 and 5) are selected as candidates. Group 6 is omitted because the process is already highly automated. Groups $2,3,7$ and 8 are assessed based on additional requirements to evaluate whether they are potential candidates. However, these did not qualify for further enquiry.

Step 3: Technology analysis. For the selected groups, available technologies are identified based on internet searches and technical expertise, within the company and with external experts. These are characterized in terms of technological maturity, including working reliability, and level of adaptation required in order to implement the technology, and mapped in a framework. The left part of Fig. 2 shows an example where technologies for group 4 are mapped according to the two dimensions.
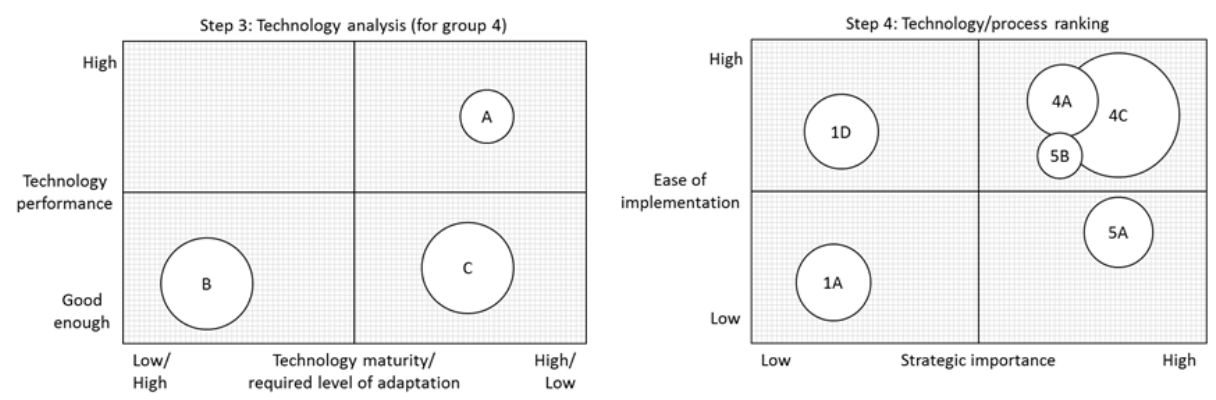

Fig. 2. Examples of technology analysis and technology/process ranking

Circles A, B and C represent three different pipe bending technologies. The size of each circle represents the total amount of products that the technology is able to process. Technology A is mature but can only handle $30 \%$ of the total volume. Technology $\mathrm{C}$ is possible to use for $100 \%$ of the volume; however, its cycle time is significantly lower. Technology B has low performance as well as low maturity, making it a less desirable candidate. Based on this mapping, technology $\mathrm{A}$ and $\mathrm{C}$ are selected for the next step. Similar mappings are carried out for groups 1 and 5.

Step 4: Technology/process ranking. Next, the selected candidates of alternative process/technology combinations are assessed in terms of ease of implementation and strategic importance. The right part of Fig. 2 above illustrates the positioning of different technologies for different product groups according to the two dimensions. The sizes of the circles indicate the share of products the technology is able to handle. By weighting the alternatives, final automation project priority came out as: $4 \mathrm{C}, 4 \mathrm{~A}, 5 \mathrm{~B}$, 1D and 1A. Project 5A was discarded due to its lack of ease of implementation, although aspects of design for automation aspects were considered that might have helped to simplify implementation.

Step 5: Investment and implementation. The company is working on business cases showing the viability of the suggested automation projects. Being a part of an international group, it follows a corporate template for investment proposals. Several of the analyses proposed in the approach are carried out in order to fulfill the group management's requirements for investment proposals. 


\section{Conclusions}

Automation technology constitutes a critical element for Norwegian manufacturing industry to increase productivity and stay competitive. Making sound automation decisions at the first attempt is crucial; however, existing models for selection of automation initiatives are not being used by industry due to their high complexity. In response, this paper presents a strategic approach for selecting automation technology projects that intends to be simple and efficient to use. The approach mainly addresses the early phases of the technology selection process, and contributes with improved understanding of how companies systematically can select appropriate automation initiatives. It has been developed based on literature and in collaboration with two case companies by utilizing the action research method.

The results represent a first version of the approach. Involved case company representatives and colleagues participating in the two projects have given positive feedback on the approach. More research is needed to develop it into a more consistent methodology. Planned activities include testing and developing the approach on specific automation initiatives in case companies. Key dimensions of the approach will be further specified including evaluation criteria for the different steps. Further work will focus on aspects related to high product variation.

Acknowledgements. We are grateful to The Research Council of Norway for funding this research. We would also like to express our appreciation to colleagues, especially Lars Erik Wetterwald, and case companies involved in the projects Effective Production of Advanced Maritime Equipment (EFFEKT) and Sustainable Multi-variant Manufacturing in Semi-process Industry (MIX), and the Center for Research-based Innovation Norwegian Manufacturing Future (SFI Norman), for their contribution.

\section{References}

1. Gouvea Da Costa, S.E., Platts, K.W., Fleury, A.: Strategic selection of advanced manufacturing technologies (AMT), based on the manufacturing vision. International Journal of Computer Applications in Technology 27, 12-23 (2006)

2. Small, M.H.: Planning, justifying and installing advanced manufacturing technology: a managerial framework. Journal of Manufacturing Technology Management 18, 513-537 (2007)

3. Chung, C.A.: Human issues influencing the successful implementation of advanced manufacturing technology. Journal of Eng. and Tech. Manag. 13, 283-299 (1996)

4. Mehrabi, M.G., Ulsoy, A.G., Koren, Y., Heytler, P.: Trends and perspectives in flexible and reconfigurable manufacturing systems. Journal of Intelligent Manufacturing 13, 135-146 (2002)

5. Morgan, L.O., Daniels, R.L.: Integrating product mix and technology adoption decisions: a portfolio approach for evaluating advanced technologies in the automobile industry. Journal of Operations Management 19, 219-238 (2001)

6. Torkkeli, M., Tuominen, M.: The contribution of technology selection to core competencies. International Journal of Production Economics 77, 271-284 (2002)

7. Farooq, S.: Manufacturing technology selection: a supply chain perspective. University of Nottingham (2007) 
8. Raafat, F.: A comprehensive bibliography on justification of advanced manufacturing systems. Int J Prod Econ 79, 197-208 (2002)

9. Chan, F., Chan, M., Lau, H., Ip, R.: Investment appraisal techniques for advanced manufacturing technology (AMT): a literature review. Integrated Manufacturing Systems 12, 35-47 (2001)

10. Ordoobadi, S.M., Mulvaney, N.J.: Development of a justification tool for advanced manufacturing technologies: system-wide benefits value analysis. Journal of Engineering and Technology Management 18, 157-184 (2001)

11. Goyal, S., Grover, S.: Advanced manufacturing technology effectiveness: A review of literature and some issues. Front. Mech. Eng. 7, 256-267 (2012)

12. Sjøbakk, B., Thomassen, M.K., Alfnes, E.: Automation in the ETO Production Situation: The Case of a Norwegian Supplier of Ship Equipment. In: International Workshop of Advanced Manufacturing and Automation. Akademika forlag, (2013)

13. Wadhwa, R.S.: Flexibility in manufacturing automation: A living lab case study of Norwegian metalcasting SMEs. Journal of Manufacturing Systems (2012)

14. Frohm, J.: Levels of Automation in production systems. Chalmers University of Technology (2008)

15. Koren, Y., Shpitalni, M.: Design of reconfigurable manufacturing systems. Journal of Manufacturing Systems 29, 130-141 (2010)

16. Farooq, S., O'Brien, C.: An analytical approach to strategic technology selection. In: 19th International Conference on Production Research. (2007)

17. Kengpol, A., O'Brien, C.: The development of a decision support tool for the selection of advanced technology to achieve rapid product development. International Journal of Production Economics 69, 177-191 (2001)

18. Efstathiades, A., Tassou, S., Antoniou, A.: Strategic planning, transfer and implementation of Advanced Manufacturing Technologies (AMT). Development of an integrated process plan. Technovation 22, 201-212 (2002)

19. Chan, F., Chan, M., Tang, N.: Evaluation methodologies for technology selection. Journal of Materials Processing Technology 107, 330-337 (2000)

20. Greitemann, J., Plehn, C., Koch, J., Reinhart, G.: Strategic Screening of Manufacturing Technologies. Enabling Manufacturing Competitiveness and Economic Sustainability, pp. 321-326. Springer (2014)

21. Phaal, R., Farrukh, C., Probert, D.: Technology management process assessment: a case study. International Journal of Operations \& Production Management 21, 1116-1132 (2001)

22. Chuang, M., Yang, Y.S., Lin, C.T.: Production technology selection: Deploying market requirements, competitive and operational strategies, and manufacturing attributes. International Journal of Computer Integrated Manufacturing 22, 345-355 (2009)

23. Shehabuddeen, N., Probert, D., Phaal, R.: From theory to practice: challenges in operationalising a technology selection framework. Technovation 26, 324-335 (2006)

24. Punniyamoorthy, M., Ragavan, P.: A strategic decision model for the justification of technology selection. Int. J. of Adv. Manu. Techn. 21, $72-78$ (2003) 